\title{
PENGARUH CORPORATE ENTREPRENEURIAL INTENTION DAN SELF- EFFICACY TERHADAP ENTREPRENEURIAL INTENTION DAN ORGANIZATIONAL PERFORMANCE
}

\author{
Okto Aditya Suryawirawan ${ }^{a}$ \\ Arif Firmansyah $^{\text {b }}$ \\ ${ }^{a}$ Sekolah Pascasarjana Universitas Airlangga ${ }^{b}$ Fakultas Ekonomi dan Bisnis Universitas Airlangga \\ Email: oktoaditya@yandex.com ${ }^{\mathrm{a}}$; arif.firmansyah@feb.unair.ac.id ${ }^{\mathrm{b}}$
}

ARTICLE HISTORY

Received:

1 Februari 2019

Revised

9 March 2019

Accepted:

26 March 2019

Online available:

14 Mei 2019

Keywords (Calibri 10): entrepreneurship, corporate entrepreneurial intention, innovativeness, risk taking, proactiveness, entrepreneurial intention, organizational performance, selfefficacy

*Correspondence:

Name:

E-mail: ........

\begin{abstract}
Introduction: This study aims to examine the effect of corporate entrepreneurial intentions consisting of innovation, risk taking, and proactiveness on entrepreneurial intentions and organizational performance, with self-efficacy as a variable that moderates the influence between corporate entrepreneurial intentions and entrepreneurial intentions in Citraland Surabaya.

Methods: This study uses quantitative methods and the samples used are employees from various departments at Citraland Surabaya. The instrument used in this study was a questionnaire, then tested the relationship between variables with partial least squares, using the SmartPLS software.

Results: The results of this study indicate that there is a positive and insignificant effect of innovation on entrepreneurial intentions, a negative and insignificant effect of risk taking on entrepreneurial intentions, and a non-significant positive effect on entrepreneurial intentions. This study also found that the overall variables of corporate entrepreneurial intention had a positive and insignificant effect on organizational performance. The moderator variable in the form of selfefficacy was found to be unable to moderate the effect of the company's entrepreneurial intentions on entrepreneurial intentions.

Conclusion and suggestion: The company can also facilitate the entrepreneurial interest of these employees by giving them higher authority when the company establishes new branches. It is hoped that the company will realize the importance of fostering interest in the company, and how this will provide them with future retirement.
\end{abstract}




\begin{abstract}
ABSTRAK
Tingkat pengangguran yang tinggi di Indonesia membutuhkan solusi sesegera mungkin. Salah satunya adalah melalui penciptaan lapangan kerja yang lebih banyak. Hal ini dapat dilakukan dengan mengembangkan kewirausahaan yang ada di dalam perusahaan-perusahaan yang sudah ada, sehingga karyawan dapat berkembang minat kewirausahaannya. Perusahaan juga dapat memfasilitasi minat kewirausahaan karyawan tersebut dengan cara memberi mereka wewenang yang lebih tinggi pada saat perusahaan mendirikan cabang baru. Konsep ini dinamakan corporate entrepreneurial intention dimana kewirausahaan terjadi di dalam perusahaan yang sudah berdiri. Dengan adanya penelitian ini diharapkan perusahaan menemukan pentingnya pembinaan minat berwirausaha di dalam perusahaan, dan bagaimana itu dapat menjadi bekal mereka nanti setelah pensiun.

Penelitian ini bertujuan untuk menguji pengaruh corporate entrepreneurial intention yang terdiri dari innovativeness, risk taking, dan proactive terhadap entrepreneurial intention dan organizational performance, dengan self-efficacy sebagai variabel yang memoderasi pengaruh antara corporate entrepreneurial intention dan entrepreneurial intention di Citraland Surabaya. Jenis penelitian ini adalah kuantitatif dan sample yang digunakan adalah karyawan dari berbagai departemen di Citraland Surabaya. Instrumen yang digunakan di dalam penelitian ini adalah kuesioner, kemudian diuji hubungan antar variabelnya dengan partial least square, dengan menggunakan software SmartPLS.

Hasil penelitian ini menunjukkan bahwa terdapat pengaruh positif tidak signifikan innovativeness terhadap entrepreneurial intention, pengaruh negatif tidak signifikan risk taking terhadap entrepreneurial intention, dan pengaruh positif tidak signifikan proactiveness terhadap entrepreneurial intention. Penelitian ini juga menemukan bahwa keseluruhan variabel corporate entrepreneurial intention berpengaruh positif tidak signifikan terhadap organizational performance. Variabel moderator berupa self-efficacy ditemukan tidak mampu memoderasi pengaruh corporate entrepreneurial intention terhadap entrepreneurial intention.
\end{abstract}

\title{
INTRODUCTION
}

Lapangan kerja di Indonesia masih jauh dari cukup untuk menampung tenaga kerja yang ada, walaupun dengan jumlah penduduk Indonesia yang besar kesempatan untuk mendirikan bisnis sebenarnya sangat terbuka lebar, karena itu sangat penting untuk menumbuhkan minat kewirausahaan pada penduduk di Indonesia, sehingga

Published by University of Airlangga.

This is an open access article under the CC BY license (https://creativecommons.org/licenses/by-sa/4.0/) 
mereka khususnya angkatan kerja yang ada, tidak hanya berorientasi untuk bekerja sebagai pegawai, tetapi juga menjadi penyedia lapangan kerja, semakin banyak usaha baru yang berdiri, semakin luas pula lapangan kerja bagi angkatan kerja yang sangat tinggi tingkat penawarannya, dibandingkan tingkat permintaannya. Landes (1998) dalam Ciputra (2011) menyatakan bahwa kekayaan dan kemiskinan dari negara berkembang, telah dikaitkan dalam dunia modern dengan sifat entrepreneurial dari ekonomi mereka. Wirausaha (entrepreneur) memiliki pengaruh yang besar dalam pembangunan ekonomi melalui penciptaan inovasi, lapangan kerja, dan kesejahteraan. Dunia usaha yang dibangun oleh entrepreneur akan mendorong perkembangan sektor-sektor produktif. Semakin banyak suatu negara memiliki entrepreneur akan semakin mendorong berkembangnya sektor-sektor produktif. Entrepreneur juga dapat memperkenalkan produk baru atau produk dengan kualitas yang baru, memperkenalkan metode produksi baru, membuka pasar baru, memperoleh sumber pasokan baru dari bahan atau komponen yang baru, serta menjalankan organisasi baru didalam industri (Schumpeter, 1934) dalam Darwanto (2012). Kegiatan produktif tersebut dapat meningkatkan output pembangunan ekonomi sehingga seharusnya karyawan diberikan dukungan yang lebih pada pembentukan minat kewirausahaan (entrepreneurship) sebagai akselerator pembangunan (Darwanto, 2012).

Ciputra (2011) menyatakan bahwa ketertinggalan Indonesia dibandingkan dengan Singapura dan Malaysia adalah karena jumlah entrepreneur yang terlalu sedikit, menurut Ciputra apabila Indonesia dipenuhi oleh entrepreneur maka Indonesia akan semakin sejahtera. Entreprenur ini akan membuka lapangan kerja yang lebih banyak, mengolah kekayaan alam Indonesia sehingga memiliki nilai tambah yang lebih besar dan dipasarkan ke seluruh dunia, dan keindahan alam dan budaya Indonesia dari Sabang sampai Merauke akan menjadi sumber devisa bagi negara. Phelps (2006) dalam Ciputra (2011) juga menyatakan bahwa entrepreneurship dan insititusi ekonomi yang memfasilitasinya, akan memiliki dampak pada kehidupan masyarakat dan juga aspek sosial seperti produktifitas nasional, tingkat gaji dan pengangguran. Ciputra (2011) menyatakan bahwa kewirausahaan memiliki makna kecakapan mengubah kotoran dan rongsokan menjadi emas, dan untuk mengubah kotoran menjadi emas tersebut, diperlukan adanya perubahan yang kreatif dan dramatis, selain itu kotoran dan rongsokan tersebut harus diubah menjadi sesuatu yang bernilai dalam persepsi pasar, bukan hanya kreatif menurut penciptanya.

Melalui wawancara yang dilakukan dengan salah satu manajer Citraland, penelitian ini mencoba melihat implementasi dari pernyataan-pernyataan mengenai entrepreneurship yang diberikan oleh Ciputra di bagian sebelumnya terhadap karyawan di perusahaan. Manajer tersebut mengemukakan bahwa penanaman entrepreneurship di Citraland memang diharapkan dapat muncul di seluruh sektor, tidak hanya di bagian 
yang terdepan saja seperti bagian marketing atau penjualan. Di Citraland setiap karyawan memiliki kesempatan untuk mendapatkan rotasi, yang menurut manajer mampu meningkatkan entrepreneurship. Semua karyawan diharapkan memiliki inovasi, kreativitas, dan proaktif, di bidangnya asing-masing. Semua ide-ide akan sangat ditampung oleh perusahaan dalam hal ini Citraland. Pada departemen teknik, karyawan dituntut untuk selalu berinovasi karena merupakan bagian yang melakukan perancangan dan pembangunan yang merupakan inti dari bisnis Citraland, bagaimana departemen tersebut mengusahakan rancangan baru, atau proses pembangunan baru, desain baru. Pada departemen marketing dipaparkan mengenai bagaimana mereka menyusun strategi pemasaran atau penjualan, kemudian pada departemen keuangan seperti bagaimana menciptakan cara pembayaran yang fleksibel, mengusakahan terciptanya kemudahan pembayaran baik terkait konsumen, rekanan, atau kontraktor walaupun sudah terdapat aturan baku pada proses yang mereka lakukan. Pada bagian sumber daya manusia karyawan diberi kesempatan untuk memberikan pelatihan atau mengikuti pelatihan baik internal maupun eksternal, bagaimana bagian sumber daya manusia menentukan pelatihan yang sesuai bagi karyawan, dan mereka juga diberikan kesempatan untuk mengajarkan ilmu-ilmu yang mereka miliki, sebagai bagian dari kesempatan yang diberikan perusahaan pada karyawan untuk mengasah diri mereka. Di semua departemen, karyawan memiliki kesempatan seluas-luasnya untuk mengembangkan diri mereka, melakukan inovasi dan kreativitas dibidangnya masingmasing, selama hal tersebut dilakukan dalam rangka memajukan perusahaan.

Citraland juga memberikan dukungan terhadap pengambilan resiko, perusahaan akan mengolah usulan dari tiap karyawan secara bersama-sama dalam sebuah forum, dan dikaji apa resiko yang berada dibaliknya, sehingga kemudian muncul beberapa alternatif usulan, dan karyawan mampu melihat usulan dari forum yang ada tersebut dan mampu melihat usulan mana yang memiliki hasil paling besar dengan resiko yang paling kecil. Setiap ide dari setiap lapisan karyawan ditampung oleh perusahaan, dan apabila keputusan telah diambil maka keputusan tersebut merupakan keputusan bersama dan menjadi tanggung jawab bersama, budaya inilah yang dianggap perusahaan sebagai dukungan terhadap pengambilan resiko pada karyawan di Citraland. Penelitian ini kemudian mencoba meneliti faktor-faktor yang memiliki dampak terhadap niatan karyawan untuk menjadi entrepreneur.

Penelitian terkait faktor-faktor yang dapat mempengaruhi keputusan untuk mendirikan bisnis terkait erat dengan karakteristik atau kepribadian dari seorang individu (McCLelland, 1961; Brockhaus, 1980; Krueger, 2000) dalam Ferreira, Raposo, Rodrigues, Dinis, dan Paco (2012). Mitton (1989) dalam Ferreira et al. (2012) menjelaskan entrepreneur sebagai orang yang memiliki psychological characteristic 
seperti komitmen terhadap pekerjaan mereka, kebutuhan akan kendali secara penuh, dan juga kesukaan terhadap ketidakpastian dan tantangan. Bygrave (1989) dalam Ferreira et al. (2012) mempresentasikan model yang mengikutsertakan need for achievement, internal locus of control, tolerance for ambiguity dan risk-taking propensity, yang merupakan bagian dari psychological characteristic sebagai faktor penentu entrepreneurial intention. Penelitian ini melihat bahwa secara parsial, konsep tersebut memiliki kemiripan dengan konsep entrepreneurial orientation yang di cetuskan oleh Lumpkin dan Dess (1996), dimana salah satu dari ketiga faktor utama dari entrepreneurial orientation adalah termasuk risk taking. Robinson et al. (1991) dalam Ferreira et al. (2012) juga menyatakan bahwa achievement, innovativeness, locus of control, dan self-confidence dapat memprediksi entrepreneurial attitudes. Penelitian ini melihat bahwa secara parsial, konsep tersebut juga memiliki kemiripan dengan konsep entrepreneurial orientation dimana salah satu dari ketiga faktor utama dari entrepreneurial orientation adalah termasuk innovativeness.

Bateman dan Crant (1993) dalam Crant (1996) menyatakan bahwa proactive personality memiliki implikasi terhadap pemilihan pekerjaan khususnya entrepreneurship. Berdasarkan penjelasan tersebut maka perusahaan yang mendukung karakteristik risk taking, innovativeness, dan proactive personality dari karyawan, akan mampu meningkatkan entreprenurial intention karyawan tersebut.

Dengan melihat transisi individu dari karyawan menuju entrepreneur sebagai akibat dari adanya entrepreneurial orientation, terdapat konsep yang dinamakan corporate entrepreneurial intention, dimana organisasi dapat memfasilitasi entrepreneurial intention dari karyawan dengan mendirikan cabang perusahaan yang baru, atau anak perusahaan yang baru (Mangematin et al. (2003) dalam Fini, Grimaldi, Marzocchi, Sobrero (2010). Keputusan apapun yang akan diambil oleh karyawan melalui entrepreneurial intention atau perusahaan melalui corporate entrepreneurial intention, tetap memiliki andil dalam usaha peningkatan lapangan kerja demi menurunkan tingkat pengangguran, dengan asumsi bahwa corporate entrepreneurial intention yang dapat didukung oleh perusahaan mampu meningkatkan entrepreneurial intention. Finn et al. (2010) menyatakan bahwa konsep corporate entreprenurial intention didasari oleh aspek innovativeness, proactiveness, dan riskiness, sehingga dapat disimpulkan bahwa konsep corporate entrepreneurial intention serupa dengan konsep entrepreneurial orientation yang telah dipaparkan diatas.

Fishbein dan Ajzen (1975) dalam Boyd \& Vozikis (1994) menyatakan bahwa konsep intention adalah fungsi dari kepercayaan yang menciptakan hubungan antara kepercayaan dengan perilaku yang berkaitan, dimana seseorang akan membentuk sikap terhadap perilaku berdasarkan kepercayaan bahwa dengan menunjukkan perilaku tersebut, akan dapat menghasilkan konsekuensi tertentu. Hal inilah yang menjadi dasar 
dari konsep Birds (1988) dalam Boyd \& Vozikis (1994), yang menyatakan bahwa konsep self-efficacy terintegrasi dengan pengembangan entreprenurial intentions dan entrepreneurial behavior. Self-efficacy adalah tingkatan dimana seseorang merasa mampu untuk melakukan sesuatu (Krueger, 1993 dalam Boyd dan Vozikis, 1994). Bandura (1977a, 1977b, 1982) dalam Boyd \& Vozikis (1994) juga menyatakan bahwa konsep self-efficacy, yang diambil dari teori pembelajaran sosial, memiliki peran penting dalam pengembangan entrepreneurial intention dan entrepreneurial action. Tanpa adanya tingkatan tertentu dari self-efficacy maka sangat tidak mungkin seorang calon entrepreneur akan termotivasi untuk menjalankan proses pendirian perusahaan baru (Boyd dan Vozikis, 1994; Krueger dan Brazeal, 1994; Markman et al., 2002; Zhao et al., 2005 dalam Hmieleski dan Baron, 2008).

Serangkaian penelitian yang dilakukan sebelumnya melihat konsep entrepreneurial orientation memiliki implikasi terhadap performa perusahaan dan juga pertumbuhan ekonomi (Birhinshaw, 1997; Burgelman 1983; Collines et al., 2004) dalam Bhuian et al. (2010). Serangkaian penelitian sebelumnya juga menemukan dampak langsung konsep entrepreneurial orientation terhadap firm performance (Zahra, 1991; Zahra dan Covin, 1995 dalam Chow, 2006; Moris et al., 1994; Colvin dan Slevin, 1989 dalam Bhuian et al., 2010). Slevin (1993) dalam Lumpkin dan Dess (1996) juga menemukan hubungan yang positif antara fit dan performance pada perusahaan dalam lingkungan yang turbulent, yang memiliki gaya yang innovative, risk taking, dan proactive. Dari paparan diatas penelitian ini dilakukan untuk melihat dampak corporate entrepreneurial intention yang terdiri dari risk taking, innovativeness, dan proactive personality terhadap entrepreneurial intention dan organizational performance. Penelitian ini juga melihat apakah self-efficacy mampu meningkatkan pengaruh corporate entrepreneurial intention terhadap entrepreneurial intention.

Penelitian mengenai corporate entrepreneurial intention banyak dilakukan pada perusahaan yang sudah besar dan sudah berdiri lama, dimana kelompok manajemen puncak, melalui proses top-down, mengambil keputusan tentang kapan dan bagaimana melakukan tindakan entrepreneurial, dan merancang mekanisme tingkat organisasi yang berkaitan, sertia menciptakan insentif untuk memelihara perilaku entrepreneur. Formalisasi dari prosedur yang mendukung perilaku tersebut, menciptakan rutinitas didalam sebuah organisasi (Phan et al., 2009; Zahra dan Filatotchev, 2004 dalam Fini et al., 2010).

\section{LITERATURE REVIEW}

Konsep proactiveness sejalan dengan konsep propensity to act dari konsep Shapero (1982). Model ini menurut Krueger (1993) dalam Krueger dan Brazeal (1994) 
memiliki kaitan erat dengan locus of control. Dan keinginan untuk memiiki kendali atas sesuatu tersebut memiliki hubungan yang signifikan terhadap entrepreneurial intention. Shapero dan Sokol (1982) dalam Crant (1996) menyatakan terdapat kecenderungan terhadap tindakan dan inisiatif terkait dimensi sosial dari peristiwa entrepreneurial. Batemant dan Crant (1993) dalam Crant (1996) menyatakan bahwa proactive personality memiliki implikasi terhadap pilihan pekerjaan khususnya entrepreneurship. Krueger dan Brazeal (1994) dalam Crant (1996) juga menyatakan bahwa konsep propensity to act memiliki kaitan yang erat dengan entrepreneurial intentions dan entrepreneurial potential.

Berdasarkan beberapa pendapat sebelumnya maka:

$\mathrm{H} 1$ : Innovativeness berpengaruh positif terhadap entrepreneurial intention karyawan.

H2: Risk taking berpengaruh positif terhadap entrepreneurial intention karyawan

H3: Proactive berpengaruh positif terhadap entrepreneurial intention karyawan

Menurut Bandura (1986) dalam Poon dan Junit (2009), penentuan akan perasaan bahwa seseorang tersebut memiliki kemampuan, tidak hanya mempengaruhi pilihan aktifitas seseorang, tetapi juga tingkat usaha dan ketahanan mereka. Ketika menghadapi persepsi akan sebuah rintangan ataupun rintangan yang sesungguhnya, individu dengan self-efficacy yang tinggi memperlihatkan usaha yang lebih baik dibandingkan mereka yang memiliki self-efficacy yang rendah. Oleh karena itu, apabila entrepreneur memiliki perasaan mampu akan sesuatu, mereka akan lebih mau untuk menghadapi rintangan dalam memperkenalkan produk baru, melakukan tindakan didalam lingkungan, dan mengambil proyek yang beresiko karena mereka percaya akan kemampuan mereka. Sehingga dapat diambil kesimpulan bahwa seseorang yang memiliki self-efficacy yang tinggi akan menciptakan lingkungan kerja yang memiliki entrepreneurial orientation, yaitu menunjukkan perilaku innovative, proactive, dan risk taking. Krueger (1993) dalam Boyd dan Vozikis (1994) juga menyatakan bahwa konsep perceived feasibility yang sejalan dengan konsep self-efficacy yang merupakan tingkatan dimana seseorang merasa mampu untuk melakukan sesuatu, sangat berpengaruh terhadap entrepreneurial intention. Sehingga dapat disimpulkan bahwa semakin tinggi rasa mampu dari seseorang untuk menunjukkan perilaku innovative, proactive, dan risk taking, maka akan meningkatkan keinginan orang tersebut untuk mendirikan perusahaan.

Berdasarkan paparan diatas, maka:

H4: Self-efficacy mampu meningkatkan pengaruh innovativeness terhadap entrepreneurial intention secara signifikan.

H5: Self-efficacy mampu meningkatkan pengaruh risk taking terhadap entrepreneurial intention secara signifikan.

H6: Self-efficacy mampu meningkatkan pengaruh proactive terhadap entrepreneurial intention secara signifikan. 
Pada lingkungan yang terus menerus mengalami perubahan, produk dan model siklus bisnis yang semakin pendek, keuntungan dimasa depan dari operasional perusahaan yang ada semakin tidak pasti, dan bisnis membutuhkan pencarian yang konstan terhadap kesempatan-kesempatan baru. Karena itu perusahaan dapat memperoleh keuntungan dari penerapan corporate entrepreneurial intention (Lumpkin dan Dess, 1994). Perusahaan yang menerapkan corporate entrepreneurial intention sering melakan inovasi sementara mengambil resiko didalam strategi product-market mereka (Miller dan Frisien, 1982 dalam Lumpkin dan Dess, 1994). Usaha untuk mengantisipasi permintaan dan secara agresif menempatkan produk baru seringkali menghasilkan performa perusahaan yang tinggi (Ireland et al., 2003 dalam Rauch et al., 2009). Dari paparan diatas, dapat disimpulkan bahwa entrepreneurial orientation dapat mengakibatkan performa yang tinggi. Bhuian et al. (2010) dalam penelitiannya juga menyatakan bahwa innovativeness, risk taking, dan proactiveness memiliki dampak langsung terhadap performa organisasi. Pernyataan tersebut didukung oleh serangkaian penelitian yang menemukan bahwa perusahaan yang menerapkan corporate entrepreneurial intention memiliki performa yang lebih baik dibandingkan perusahaan yang tidak menerapkan corporate entrepreneurial intention (Covin dan Slevin, 1986; Hult et al., 2003; Lee et al., 2001; Wiklund dan Shepherd, 2003 dalam Rauch et al., 2009). Berdasarkan beberapa pendapat tersebut maka:

H7: Innovativeness berpengaruh positif terhadap organizational performance karyawan. H8: Risk taking berpengaruh positif terhadap organizational performance karyawan H9: Proactive berpengaruh positif terhadap organizational performance karyawan

\section{RESEARCH METHODS}

Kuisioner diberikan kepada karyawan perusahaan Citraland yang dianggap mengerti seluk beluk perusahaan dan informasi mengenai performa perusahaan dari segi non-finansial. Batasan populasi dan sampel yang digunakan dalam penelitian ini antara lain adalah karyawan dari berbagai departemen, yang bekerja di Citraland. Melalui wawancara dengan salah satu manajer dari Citraland, dapat disimpulkan bahwa seluruh karyawan memahami dengan baik budaya entrepreneurship yang ditanamkan di dalam perusahaan dan mereka dapat dengan mudah mendapatkan informasi mengenai aspek non-finansial terkait dengan performa perusahaan. Maka dari itu peneliti memerlukan setidaknya 30 responden untuk melakukan pengujian. Kuesioner yang disebarkan sebanyak 70 kuesioner namun yang kembali berjumlah 54 kuisioner dan yang dapat digunakan pada penelitian ini berjumlah 49 kuesioner. Dari 49 responden tersebut responden laki-laki sebanyak 16 orang dan perempuan sebanyak 33 orang.

Published by University of Airlangga.

This is an open access article under the CC BY license (https://creativecommons.org/licenses/by-sa/4.0/) 
Penilaian terhadap pernyataan responden diukur dengan menggunakan skala yang telah dimodifikasi menjadi 4 tingkat untuk mengeliminasi kelemahan yang dikandung oleh skala 5 tingkat, karena seringkali poin tengah atau poin netral digunakan responden ketika mereka tidak yakin dengan pilihannya, serta untuk menghindari central tendency sehingga dapat diketahui dengan jelas arah dari jawaban responden (Kulas, 2008 dalam Tsang, 2012).

\section{RESULT AND ANALYSIS}

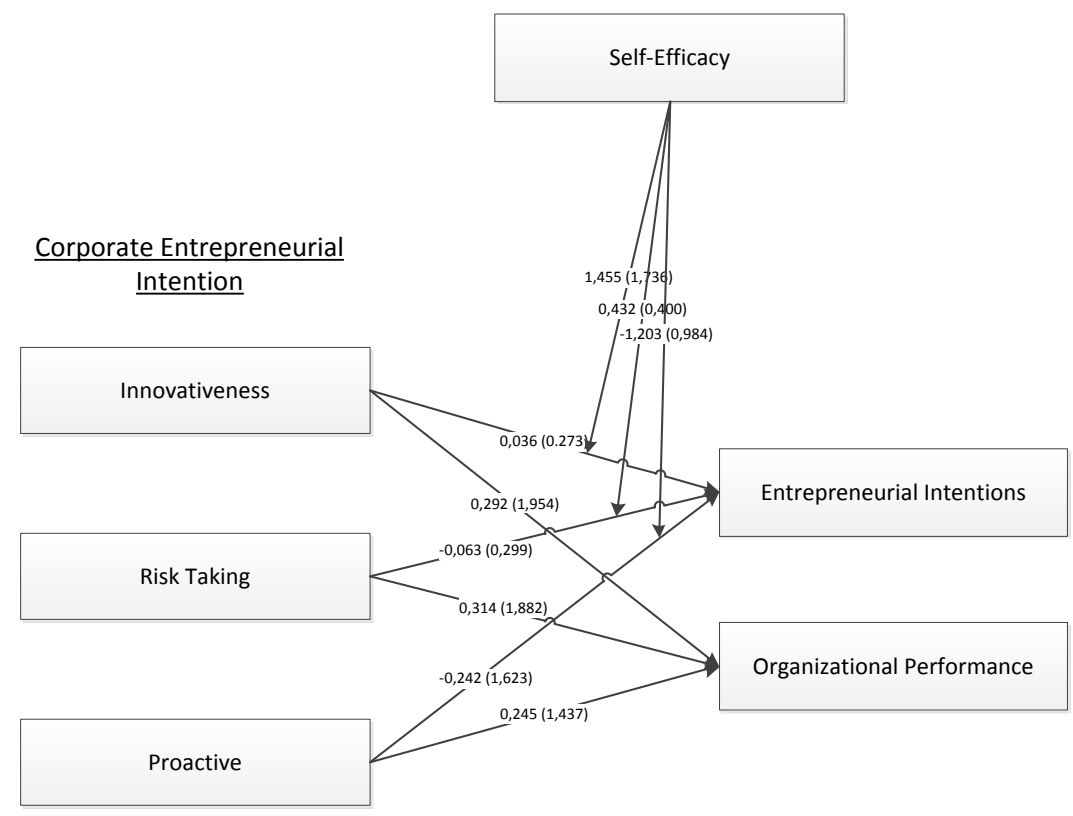

Gambar 1

Model Empiris dan Hasil olah

Terdapat hubungan positif antara innovativeness (I) dengan entrepreneurial intention (EI). Hal tersebut tampak pada nilai original sample I>EI sebesar 0.037. Hubungan positif tersebut tidak signifikan dikarenakan nilai T Statistic I>EI sebesar 0,273 atau < 1,96. Hasil tersebut sejalan dengan penelitian Ferreira et al. (2012) yang tidak menemukan pengaruh signifikan innoativeness terhadap entrepreneurial intention, namun meskipun begitu, pengaruh positif yang ada pada penelitian ini sejalan dengan serangkaian penelitian yang menemukan pengaruh positif innovativeness terhadap entrepreneurial intention (Koh, 1996; Bygrave, 1989; Robinson et al., 1991).

Terdapat hubungan negatif antara risk taking $(\mathrm{R})$ dengan entrepreneurial intention (EI). Hal tersebut tampak pada nilai original sample R>El sebesar -0.063 . Hubungan positif tersebut tidak signifikan dikarenakan nilai T Statistic R>EI sebesar 0,299 atau $<1,96$. Hasil tersebut sejalan dengan penelitian Ferreira et al. (2012) yang tidak menemukan pengaruh signifikan risk taking terhadap entrepreneurial intention. Hasil dari penelitian ini bertentangan dengan serangkaian penelitian yang menemukan pengaruh positif risk taking terhadap entrepreneurial intention (Koh, 1996; Bygrave, 
1989; Robinson et al., 1991), hal ini dapat disebabkan oleh karakteristik jawaban responden pada pertanyaan seputar kemauan mereka dalam mengambil resiko. Dari karakteristik jawaban responden, pertanyaan seputar risk taking memiliki mean terendah (2,75), dari angka tersebut dapat terlihat bahwa responden cenderung menjawab dengan tidak setuju dan sangat tidak setuju pada pertanyaan seputar pengambilan keputusan yang sifatnya tidak pasti, dan lebih dari setengah responden menjawab tidak setuju dan sangat tidak setuju pada pertanyaan seputar pengambilan keputusan yang mampu membahayakan karier mereka di dalam perusahaan. Hal ini menunjukkan bahwa posisi mereka di dalam perusahaan sebagai karyawan masih memegang peranan penting bagi mereka meskipun mereka memiliki kemauan yang besar untuk berwirausaha. Hasil wawancara juga mengatakan bahwa semua pengambilan keputusan yang beresiko akan ditampung dan didiskusikan resikonya secara bersama-sama, sehingga dapat disimpulkan bahwa sangat jarang terjadi situasi dimana karyawan harus mengambil keputusan sendiri yang dapat berpotensi membahayakan karier mereka di dalam perusahaan. Hudgens dan Fatkin (1985 dalam Powel dan Ansic, 1997) juga menyatakan bahwa wanita memiliki preferensi yang lebih rendah mengenai risiko dibandingkan pria. Hal ini juga dapat menjadi penyebab hasil yang bertentangan dengan landasan teori pada penelitian ini, karena dari karakteristik jenis kelamin responden pada penelitian ini, 67\%-nya adalah wanita.

Terdapat hubungan negatif antara proactiveness (I) dengan entrepreneurial intention (EI). Hal tersebut tampak pada nilai original sample $\mathrm{P}>\mathrm{EI}$ sebesar -0,242. Hubungan negatif tersebut tidak signifikan dikarenakan nilai T Statistic P>EI sebesar 1,623 atau < 1,96. Hasil dari penelitian ini tidak sejalan dengan serangkaian penelitian sebelumnya mengenai pengaruh proactiveness terhadap entrepreneurial intention (Crant, 1996; Prabhu, 2013). Hal ini dapat terjadi karena beberapa karyawan merasa bahwa perusahaan kurang memberi ruang bagi penelitian dan pengembangan, pemanfaatan teknologi baru,dan penciptaan teknologi baru di dalam perusahaan. Ragam produk atau jasa juga menurut sebagian karyawan tidak banyak, dan tidak banyak perubahan terhadap proses penciptaan produk baru. Hal tersebut dapat dikarenakan Citraland sendiri sudah berdiri cukup lama dan tidak banyak memiliki ragam produk baru khususnya di wilayah barat Surabaya.

Secara statistik Self-efficacy tidak mampu memperkuat pengaruh innovativeness $(\mathrm{I})$, risk taking $(\mathrm{R})$, dan proactiveness $(\mathrm{P})$ terhadap entrepreneurial intention (EI). Hal tersebut tampak dari nilai T Statistic $<1,96$ yang menandakan tidak signifikan. Hal ini bertentangan dengan berbagai pernyataan yang ada pada penelitian sebelumnya, yang menyatakan bahwa self-efficacy mampu meningkatkan pengaruh innovativeness, proactiveness, dan risk taking pada entrepreneurial intention (Boyd dan Vozikis, 1994). 
Hal ini dapat disebabkan karena inkonsistensi pada karakteristik jawaban responden atas kuesioner yang dibagikan pada penelitian ini. Seperti yang telah diutarakan sebelumnya, seseorang yang memiliki self-efficacy yang tinggi akan menciptakan lingkungan kerja yang menunjukkan perilaku innovative, proactive, dan risk taking (Bandura, 1986 dalam Poon dan Junit, 2009), namun sebagaimana yang sudah dipaparkan, sebagian responden memiliki tingkat proactiveness dan risk taking yang rendah, namun memiliki self-efficacy yang tinggi.

Terdapat hubungan positif antara innovativeness $(\mathrm{I})$, risk taking $(\mathrm{R})$, proactiveness (P) dengan organizational performance (OP). Hal tersebut tampak pada nilai original sample I>OP sebesar 0.292(I), 0.314(R), dan 0.245(P). Hubungan positif tersebut tidak signifikan dikarenakan nilai T Statistic $<1,96$. Pengaruh positif tersebut sejalan dengan serangkaian penelitian sebelumnya yang menyatakan bahwa entrepreneurial orientation yang terdiri dari innovativeness, risk taking, dan proactiveness berpengaruh positif terhadap organizational performance (Bhuian et al., 2010; Chow, 2006), walaupun secara statistik penelitian ini menunjukkan hasil yang tidak signifikan.

Berdasarkan hasil penelitian di atas, Citraland Surabaya harus mempertahankan ruang yang diberikan untuk inovasi dari karyawan perusahaan. Kemauan untuk mengambil resiko dari karyawan yang rendah dikarenakan memang budaya di Citraland Surabaya adalah menampung segala usulan dari karyawan dan kemudian didiskusikan bersama, namun Citraland Surabaya tetap harus meningkatkan risk taking dari karyawan dengan memberikan dukungan agar karyawan lebih berani mengambil keputusan yang sifatnya tidak pasti untuk mendukung budaya kewirausahaan yang ditanamkan dalam perushaaan. Bagi sebagian karyawan, perusahaan kurang memberikan dukungan terhadap karyawan untuk bersikap lebih proaktif, karena self-efficacy dari karyawan sebenarnya sangat tinggi. Hal ini sesuai dengan pernyataan dari Bandura (1986 dalam Poon dan Junit, 2009) yang mengatakan bahwa individu yang memiliki self-efficay yang tinggi seharusnya memperlihatkan proactiveness yang tinggi juga.

Pengaruh positif dari corporate entreprenurial intention terhadap organizational performance menunjukkan bahwa apabila perusahaan mendukung lingkungan kerja yang innovative, dukungan terhadap keputusan-keputusan yang beresiko, dan ruang untuk menunjukkan sikap yang proaktif, akan mampu meningkatkan performa dari organisasi, seperti halnya yang sudah dinyatakan oleh Bhuian et al. (2010) dan Chow (2006) pada penelitian mereka sebelumnya. Perusahaan yang mendukung budaya corporate entrepreneurial intention selain dapat meningkatkan performa organisasi, juga dapat memberikan pengembangan terhadap karyawan agar dimasa depan mereka memiliki bekal untuk memulai usaha mereka sendiri. Pengembangan tersebut mungkin tidak terlihat nyata di departemen-departemen yang tidak bersentuhan secara langsung dengan tuntutan akan innovativeness, risk taking, dan proactiveness seperti departemen 
pemasaran, dan bagian penjualan. Namun Ciputra mengatasi hal ini dengan memberikan kesempatan rotasi pekerjaan yang tinggi pada karyawan, karyawan yang memiliki kapabilitas yang sesuai dapat didukung dengan kesempatan untuk berkembang pada departemen lain. Hal ini akan memberikan karyawan kesempatan yang lebih luas untuk mengembangkan diri mereka sebagai bekal untuk berwirausaha tersebut, inilah yang patut dicontoh oleh perusahaan-perusahaan lain di Indonesia.

Inti dari penelitian ini adalah memecahkan solusi tingginya tingkat pengangguran di Indonesia. Hal tersebut dapat dicapai salah satunya adalah dengan mencetak wirausaha-wirausaha baru yang dapat menyediakan lapangan kerja yang lebih banyak bagi pengangguran tersebut. Darwanto (2012) telah menyatakan bahwa kegiatankegiatan produktif seperti berwirausaha dapat meningkatkan output pembangunan ekonomi. Ciputra (2011) juga menyatakan bahwa kesejahteraan masyarakat Indonesia akan semakin meningkat seiring dengan bertambahnya jumlah wirausaha di Indonesia. Melalui hasil wawancara yang telah dipaparkan sebelumnya dalam penelitian ini, perusahaan tidak harus takut karyawan akan keluar dari organisasi apabila mereka telah dibina minat kewirausahaannya, Ciputra menangani masalah tersebut dan menciptakan solusi berupa penugasan kepada mereka yang berprestasi kinerjanya dan sudah terlihat potensi kewirausahaannya, sebagai pimpinan di cabang-cabang baru dari perusahaan. Hal ini dapat dicontoh oleh perusahaan lain, karena metode tersebut secara tidak langsung dapat mengembangkan perusahaan dan menciptakan lapangan kerja baru bagi masyarakat di Indonesia. Pengembangan kewirausahaan di dalam perusahaan seperti inilah yang menjadi inti dari konsep corporate entrepreneurial intention seperti yang telah dipaparkan dalam serangkaian penelitian sebelumnya (Fini, 2010; Burgelman, 1983; Guth dan Ginsberg, 1990; Zahra, 1991; Sharma dan Chrisman, 1999; Saly, 2001).

\section{CONCLUSION}

Hasil penelitian ini menunjukkan bahwa terdapat pengaruh positif tidak signifikan innovativeness terhadap entrepreneurial intention, pengaruh negatif tidak signifikan risk taking terhadap entrepreneurial intention, dan pengaruh positif tidak signifikan proactiveness terhadap entrepreneurial intention. Penelitian ini juga menemukan bahwa keseluruhan variabel corporate entrepreneurial intention berpengaruh positif tidak signifikan terhadap organizational performance. Variabel moderator berupa self-efficacy ditemukan tidak mampu memoderasi pengaruh corporate entrepreneurial intention terhadap entrepreneurial intention.

Peneliti menyadari bahwa terdapat keterbatasan pada penelitian ini. Penggunaan sampel yang jumlahnya kurang dari 100 dan penelitian yang hanya dilakukan pada salah 
satu lini perusahaan mungkin menjadi kelemahan bagi penelitian ini yang menyebabkan hasil dari penelitian ini sulit untuk digeneralisasikan dan kurang menggambarkan keadaan yang sesungguhnya. Penelitian ini juga dilakukan secara kuantitatif terhadap keseluruhan karyawan yang ada di Citraland, akan lebih baik apabila penelitian selanjutnya dilakukan secara kualitatif agar lebih memahami kondisi langsung yang ada di lapangan, dan membandingkan secara spesifik, persepsi dari karyawan dan manajer mengenai konsep budaya kewirausahaan yang Ciputra berusaha tanamkan di perusahaan.

\section{REFERENCES}

Antoncic, B., Robert D. Hisrich. 2001. Intrapreneurship: Construct Refinement and CrossCultural Validation. Journal of Business Venturing. Vol. 16: 495-527

Badan Pusat Statistik. 2013. Berita Resmi Statistik. No. 35/05/Th. XVI

Bhuian, S. N, O. C. Richard., . H. M. Shamma. 2010. Entrepreneurial Orientation and Organizational Performance: The Role of Managerial Traits. Competition Forum. Vol. 8(1): 81-85

Bird, B. 1988. Implementing entrepreneurial ideas: The case for intention. The Academy of Management Review. Vol. 13(3): 442-453

Bolton, D. L., Michelle D. Lane. 2012. Individual Entrepreneurial Orientation: Development of a Measurement Instrument. Education and Training. Vol. 54 (2): $219-233$

Boyd, N. G., G. S. Vozikis. 1994. The Influence of Self-Efficacy on the Development of Entrepreneurial Intentions and Actions. Entrepreneurship Theory and Practice

Bosscher, R. J. H. Smit. 1998. Confirmatory Factor Analysis of the General Self-Efficacy Scale. Behaviour Research and Therapy. Vol. 36: 339-343

Brockhaus, R.H. 1980. Risk Taking Propensity of Entrepreneurs. Academy of Management Journal. Vol. 23(3): 509-520

Burgelman, R.A. 1983. Corporate entrepreneurship and the pursuit of Competitive Advantage. Entrepreneurship Theory and Practice. Vol. 23(3): 85-102

Campos, H. M., J. P. N. de la Parra, F. S. Parellada. 2012. The Entrepreneurial OrientationDominant Logic-performance relationship in new ventures: an exploratory quantitative study. Brazilian Admisitration Review. Vol. 9: 60-77

Chow, I. H. 2006. The Relationship Between Entrepreneurial Orientation and Firm Performance in China. S. A. M. Advanced Management Journal. Vol. 71(3): 11-21

Ciputra, A. Tanan, A. Waluyo. 2011. Ciputra Quantum Leap 2: Kenapa dan Bagaimana Entrepreneurship mengubah masa depan Bangsa dan masa depan Anda. Jakarta: Elex Media Komputindo

Crant, J.M. 1996. The Proactive Personality Scale as a Predictor of Entrepreneurial Intentions. Journal of Small Business Management. Vol. 34(3): 42-49

Darwanto. 2012. Peran Entrepreneurship Dalam Mendorong Pertumbuhan Ekonomi dan Peningkatan Kesejahteraan Masyarakat. Universitas Diponegoro

Felicio, J.A., R. Rodrigues, V. R. Caldeirinha. 2012. The effect of intrapreneurship on corporate performance. Management Decision. Vol. 50(10): 1717-1738 
Ferreira, J. J., et al. 2012. A model of entrepreneurial intention: An application of the psychological and behavioral approaches. Journal of Small Business and Enterprise Development. Vol. 19(3): 424-440

Fini, R., et al. 2010. The Determinant of Corporate Entreprenurial Intention Within Small and Newly Established Firms. Entrepreneurship Theory and Practices

Frazier, P. A., K. E. Baron, A. P. Tix. 2004. Testing Moderator and Mediator Effects in Counseling Psychology Research. Vol. 51(1): 115-134

Guth, W. D., A. Ginsberg. 1990. 'Guest Editors' Introduction: Corporate Entrepreneurship. Stratregic Management Journal. Vol. 11(4): 5-15

Hmieleski, K. M., R. A. Baron. 2008. When does Entrepreneurial Self-Efficacy Enhance versus Reduce Firm Performance. Strategic Entrepreneurship Journal. Vol. 2: 5772

Kaya, N. 2006. The impact of human resource management practices and corporate entrepreneurship on firm performance: evidence from Turkish firms. International Journal of Human Resource Management. Vol. 17(12): 2074-2090

Koh, H.C. 1996. Testing Hypoteses of Entrepreneurial Characteristic: A study of Hong Kong MBA Students. Journal of Managerial Psychology. Vol. 11(3): 12-23

Krueger Jr., N.F. D. V. Brazeal. 1994. Entrepreneurial Potential and Potential Entrepreneurs. Entrepreneurship Theory and Practice. Vol. 18(3): 91-104

Lee, L. P, K. Wong, M. D. Foo, A. Leung. 2011. Entrepreneurial intentions: The influence of organizational and individual factors. Journal of Business Venturing. Vol. 26: 124-136

Lumpkin, G. T., G. G. Dess. 1996. Clarifying the Entrepreneurial Orientation Construct and Linking It to Performance. Academy of Management Review. Vol. 21(1): 135172

Macko A., T. Tyszka. 2009. Entrepreneurship and Risk Taking. Applied Psychology: An International Review. Vol. 58(3): 469-487

Malhotra, N. K., J. Agarwal, M. Peterson. 1996. Methodological issues in cross-cultural marketing research: A state-of-the-art review. International Marketing Review. Vol. 13 (5): 7 - 43

McMullen, J. S., D. A. Shepherd. Entrepreneurial Action and The Role of Uncertainty in the Theory of Entrepreneur. Academy of Management Review. Vol. 31(1): 132152

Mustafa, H. 2000. Teknik Sampling. Bandung: Alfabeta

Naldi, L., et al. 2007. Entrepreneurial Orientation, Risk Taking, and Performance in Family Firms. Family Business Review. Vol. 20(1): 33-47

Poon, J. M. L., Raja Azimah Ainuddin, Sa'Odah Haji Junit. 2006. Effects of Self-Concept Traits and Entrepreneurial Orientation on Firm Performance. International Small Business Journal. Vol. 24(1): 61-82

Powell, M., D. Ansic. Gender differences Ni risk behaviour in Financial decision-making: An eksperimental analysis. Journal of Economic Psychology. Vol. 18: 605-628 
Rauch, A., et al. 2009. Entrepreneurial Orientation and Business Performance: An Assessment of Past Research and Suggestions for the Future. Entrepreneurship Theory and Practice. Vol. 33(3): 761-787

Richard, P.J., et al. 2009. Measuring Organizational Performance as a Dependent Variable: Towards Methodological Best Practice. Journal of Management. Vol. 35(3): 718-804

Saly, A.W. 2001. Corporate Entrepreneurship. Tinbergen Institute Research Series. Erasmus University of Rotterdam

Sharma, P. J. J. Chrisman. 1999. Towards a Reconciliation of the Definitional Issues in the Field of Corporate Entrepreneurship. Entrepreneurship: Theory and Practice. Vol. 23(3): 11-270

Souitaris, V., S. Zerbinati. A. Al-Laham. 2007. Do entrepreneurship programme raise entrepreneurial intention of science and engineering students? The effect of learning, insipiration and resources. Journal of Business Venturing. Vol. 22: 566591

Tsang, K. K. 2012. The use of midpoint on Likert Scale: The implication for educational research. Hong Kong Teachers' Centre Journal. Vol. 11: 121-130

Van Praag, C.M. 2005. Succesful Entrepreneurshi: Confronting Economic Theory with Empirical Practice. Edward Elgar: Inggris

Zahra, S. A. 1991. Predictors and Financial Outcomes of Corporate Entrepreneurship: An Exploratory Study. Journal of Business Venturing. Vol. 6(4): 259-285 